PÄÄKIRJOITUS

\title{
Teemanumero: Avoin tiede ja avoin tieto
}

\author{
Mikael Laakso \\ Hanken School of Economics \\ mikael.laakso@hanken.fi \\ https://orcid.org/0000-0003-3951-7990
}

Minulla oli kunnia toimia tämän teemanumeron vierailevana toimittajana. Olen kiitollinen Informaatiotutkimus-lehden päätoimittajalle Susanna Nykyrille ja toimituskunnalle annetusta luottamuksesta. Olen erittäin iloinen, että teemanumeron kutsu herätti laajaa kiinnostusta, joka näkyi runsaina yhteydenottoina ja materiaalitarjontana. Kiitos kaikille aktiivisuudesta!

Lisääntynyt avoimuus tieteessä ja yhteiskunnassa avaa uusia mahdollisuuksia mielenkiitoisille löydöksille sekä lyhyellä että pitkällä tähtäimellä, auttaen tiedettä eteenpäin ja tukemalla yhteiskunnan monien toimintojen kehittymistä. Informaatiotutkimuksen näkökulmasta tämä kehityssuunta lisää mahdollisuuksia tutkia sekä prosesseja että lopputuotteita, kuin myös asioiden yhteyksiä, paremmin kuin koskaan aikaisemmin. Olemme murrosvaiheessa jossa siirtyminen kohti avoimempaa tietoympäristöä on itsessään mielenkiintoinen prosessi, jota kannattaa seurata ja tutkia, sillä avoimuuden vaatima sisäinen tarkastelu nostaa usein esiin mielenkiintoisia ja jopa yllättäviä asioita. Kun lähdetään muuttamaan prosesseja ja aineistoja avoimempaan suuntaan, se nostaa usein pinnalle eri toimijoiden piileviä oletuksia, keskeisiä jännitteitä, kannustimia ja hidasteita. Tiedon avoimuuden aihepiiriä voi ja pitää lähestyä monesta eri roolista ja näkökulmasta. Hyvänä esimerkkinä ovat tässä numerossa julkaistavaksi hyväksytyt artikkelit ja katsaukset.

Avoimuuden tukeminen ja kasvattaminen järjestelmätasolla edellyttää usein vanhojen käytäntöjen muuttamista sekä olemassa olevien toimijoiden roolien ja työnjaon tarkastelua. Myös rajapinta kansallisten ja kansainvälisten käytäntöjen, standardien, vastuiden ja suositusten suhteen pitää olla hallittu Artikkeli on lisensoitu Creative Commons Nimeä-EiKaupallinen-JaaSamoin 4.o Kansainvälinen -lisenssillä Pysyvä osoite: https://doi.org/10.23978/inf. 77413 
mutta kuitenkin muovautuva jatkuvan muutospaineen alla. Tiedon avoimuus on määränpäänä selvä ja helposti ymmärrettävä mutta matka sinne on mutkikas ja haasteita täynnä. Oikotiet ja hätäiset päätökset reitin suhteen voivat johtaa monenlaiseen tehottomuuteen sekä umpikujiin. Avoimuus ei etene pitkäjänteisesti, kestävin mekanismein, ilman kovaa työtä sekä jatkuvasti päivittyvää ymmärrystä muutoksen ja uuden toimintaympäristön vaatimista edellytyksistä. Ennen kaikkea avoimuuden kasvu vaatii laaja-alaista koordinaatiota uusien ja vanhojen toimijoiden kesken kaikilla toiminnan tasoilla, jossa vanhoja oletuksia ja rakenteita kyseenalaistetaan. Tällöin avoimuutta voidaan edistää tehokkaasti ja yhteisesti sovitulla tavalla.

Olen erittäin iloinen että osana tätä numeroa julkaistaan Susanna Nykyrin, Maria Forsmannin, sekä Anne Lehdon tekemä virallinen käännös kansainvälisestä DORA-julistuksesta ${ }^{1}$. DORA-julistus kehottaa tiedekentän toimijoita tarkastelemaan tutkimuksen arvioinnin käytäntöjä. Avoimuus mahdollistaa muun muassa entistä paremmin itse sisällön ja tutkimuksen eri osien tarkastelun sekä arvioinnin. Julistuksella on tällä hetkellä 738 organisaation ja 13183 henkilön allekirjoitusta. Toivottavasti käännös kannustaa enemmän suomalaisia henkilöitä ja organisaatioita allekirjoittamaan julistuksen, joka tekona tukee siirtymistä kohti monipuolisempaa, avoimempaa ja sisältöpohjaisempaa tutkimuksen arviointia.

Haluan osoittaa kiitokset tämän numeron tukena toimineille vertaisarvioijille, joiden erinomainen työpanos on ollut arvokas. Haluaisin myös haastaa kaikki avoimen tieteen edistämisestä kiinnostuneet tutustumaan Tieteellisten Seurain Valtuuskunnan koordinoimaan työhön, jossa laaja-alaista yhteistä tahtoa kanavoidaan konkreettisiin edistysaskeliin kaikille avoimien asiantuntijaryhmien kautta $^{2}$. Yhdessä ja yhteisymmärryksessä asiat etenevät helpommin yhteisiä päämääriä kohti.

Antoisia lukuhetkiä teemanumeron parissa!

Mikael Laakso

Helsingissä 10. joulukuuta 2018

$\begin{array}{ll}1 & \text { https://sfdora.org/read/fi/ } \\ 2 & \text { https://avointiede.fi/fi/koordinatio }\end{array}$ 